\title{
Exploring the Relationship between Market Value and Accounting Numbers of Firms in Pakistan
}

\author{
SalmanRiaz (Corresponding Author) \\ PhD Scholar, Xidian University \\ PO. Box 338 No. 2, South TaiBai Road, Xi'an 710071, China \\ E-mail: grtslmn@hotmail.com \\ Yanping Liu \\ Professor of Finance, Chief Financial Officer, Xidian University \\ PO. Box 338 No. 2, South TaiBai Road, Xi'an 710071, China \\ E-mail: liuyp@xidian.edu.cn \\ SajjadHussain Khan \\ School of accountancy and finance, The University of Lahore \\ 1 km Raiwind Road off, Lahore Pakistan
}

Received: May 3, 2015 Accepted: June 14, $2015 \quad$ Published: June 14, 2015

doi:10.5296/ajfa.v7i1.7598 URL: http://dx.doi.org/10.5296/ajfa.v7i1.7598

\begin{abstract}
This study examines the relationship between accounting numbers and market prices for the Pakistani cement industry. The study covers a time span of nine years from 2005-2014. We study the influence of book value of share, breakup value of share, earning per share, gearing ratio and dividend to equity ratio on market value of share. After applying different econometric techniques we found that book value of share and earnings per share have statistically significant influence on the market price of share.
\end{abstract}

Keywords: Market price per share, book value of share, gearing ratio and earnings per share 


\section{Introduction}

It is well understood among the accounting professional that the main purpose of the accounting is to facilitate the decision making. The innovative work done by the Ball and Brown (1968) highlighted the role of accounting information in capital markets. This is now very important research area in accounting literature.An essential preference of this kind of research has become identified which classify the value importance of accounting numbers, financial statements are generally used by stakeholders to judge the economic worth of firms on the assumption that accounting number have a assured relationship with the equity market value.

The study does not assume that shareholder use only accounting data in their savings options. They suppose that if accounting information is excellent summary that evaluates of the dealings included in security prices, after that they were value related because their exercise might give a value of the firm that is close to its market value. Thus association of this studies test whether accounting numbers provide a good summary measure of the value relevant events that have been incorporated in stock prices during the reporting period.

This area is very important with regard to capital markets because accounting information is thought to facilitate the prediction of firm's future cash flows and to help investors predict the future security's risk and returns. This is the reason a huge body of literature grown up in last three decades as (Kothari, 2003; Richard \&Tinaikar, 2003). There are three approaches (industry, finance and accounting and capital market research) theory and are available in the existing literature to value a firm.

In literature there are few studies available on the financial analyst approach because of the proprietary nature of the information. On the other hand finance and accounting theory has been widely examined in the empirical literature. This approach value a firm as the present value of the expected dividends.Ohlson (1995) suggested theoretical structure on the relationship between the market value of common equity and accounting variables. This paper has been followed by many researchers who re-examined the relationship between firm value and accounting numbers using fundamental analysis.

Bar-yousef et al. (1996) conducted the first empirical study to examine the time series relationship between market value, dividends, earnings and book value. Presently a number of studies have adopted Ohlson model (Ahmed et al, 2000; Ballester et al, 1999; Callen\& Morel, 2000; Lee et al, 1999 and Morl, 1999).

The motivation of this study is to enhance the understanding of the relationship between market and accounting values in the context of Pakistan capital markets. Given the inconclusive regarding the relationship between market and book values, it is an open question as to whether the disclosure of accounting information affects share price or whether it is irrelevant to the behavior of stock prices. The main research question is at the level of firm what is the relationship between market value and accounting numbers based on the information drawn from cement sectors firms listed onKarachi stock exchange of Pakistan. 
The study investigates this question through an examination collected from a variety of resources.

Cement industry is a major indicator of economic growth and revival of any country. This industry gives the growth and improvement of infrastructure of a country. In Pakistan, positive macroeconomic indicators and governments intention of spending more on social and infrastructure development has increased the requirement for cement many folds. There are total number of units are 22. The cement industry in Pakistan has become a long way since independence when country had a less than half a million tons per annum production capacity. By now it has exceeded 10 million tons per annum as a effect of establishment of new industrialized facilities and expansion by existing units. Privatization and effective price decontrol in 1991-92 heralded a new era in which the industry has reached a level where surplus production after meeting local demand is expected in 1997.

The study consist of three sections, following sections describes the review of literature. Section three explains the data and final section includes discussion on results and conclusion.

\section{Review of Literature}

The current approach to Capital Market Research (CMR) in the accounting literature began with the work of Ball and Brown (1968). That research was the one of the first effort systematically explore the relationship between the market value and accounting numbers of firms with the exact statistical method. Ball and brown tested the hypotheses that how abnormal returns on the stock market related with the announcement of the preliminary annual Earnings per share number which was the first annual EPS figure announced to the stock exchange. They took 261 firm listed on New York Stock exchange over the time span of 1957 to 1965. They argued that the earning numbers were useful in the earnings forester error, or earning innovation was extensively related to the abnormal returns.

Seetharaman \& Rudolph, (2010) examined the role of declaration of Earning per Share (EPS) on the stock prices and argued that earning per share have significant influence on stock returns. Graham and King, (2000) used Ohlson model to examined the relationship between market values and book values, they concluded that accounting practices have significant influence on sock returns.

Willet \& Peare, (2000) studied the relationship between market values and accounting numbers for short term and long term. They document that in short run book values and market differs but have relationship in long run. Omura (2005) provided the evidence that net assets have significant relevance for market values in the Japanese stock markets. Clout (2007) studied the Australian firms and empirically reported that there is an equilibrium correlation relationship between market values and accounting numbers.

Williams (2000) attempted an effort to test whether accounting numbers are capable to predict distress in high technology industry and empirically document that accounting numbers are still predictive in high technology firms. There is a strong relationship between accounting numbers and market values of 59 firms listed on Jakarta Stock Exchange (JSX) 
reported by Suwardi (2004). Earnings have significant weight in the firm valuation ( see Pervits et al. 1994).

Kadri\& Mohammed (2007) examined the relationship between book value, earnings and market prices. They empirically found that there is significant relationship exists in the accounting numbers and market price. Petkova and Zhang, (2005) support empirically fama-French argument that market to book value ratio is a determinant of stock returns. Similarly Raj and Ramesh (1992) the effect of book ration in Japanese stock market. They found that stocks with higher market to book value ratio have earned low returns and stocks with lover book value to market ratio earned higher stock returns in Japanese stock market.

Ball et al. (1993) studied US market; they took the data for the time span f 1950-1988. They document that changes in the earnings have systematic economic determinants that are associated with the securities return variation.

Vafeas et al. (1998) for Cyprus stock market document that earnings level and changes in earnings level does matter for the explanation of stock returns in emerging stock markets. Lamont (1998) investigated the relationship between earnings and expected returns. He argued that both dividends and earnings have ability to predict the returns and earnings having information because they are correlated with business conditions.

\section{Methodology \& Variable Construction}

This study is an effort to explore the relationship between market values and accounting number for the cement industry of Pakistan. There are 22 cement companies listed on Karachi stock exchange, we took the data of 17 companies because rest of them did not provide enough information. The study covers a time span of 2005 to 2014 . At that time many events happened as many firms get merged, delisted etc. We took the data of daily prices from the Karachi Stock market and data of accounting returns came from annual report. We used market prices and market returns as dependent variable while Book Value per Share, Earnings per Share (EPS), Gearing Ratio, Dividend to equity Ratio, and Breakup Value of Shares are taken as independent variables.

To measure the suggested relationship, we firstly checked the significance of individual variable by using the simple regression. After that we include only significant variables in our final model and reject all insignificant ones.

Following are the models

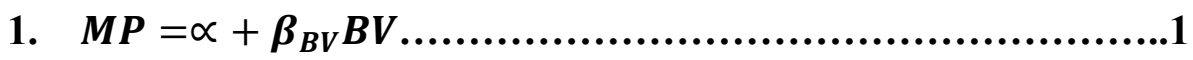

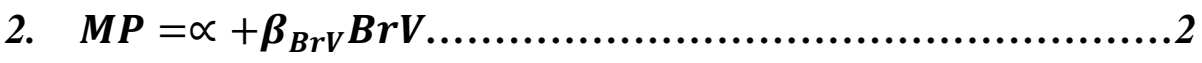

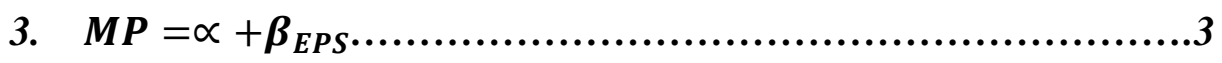




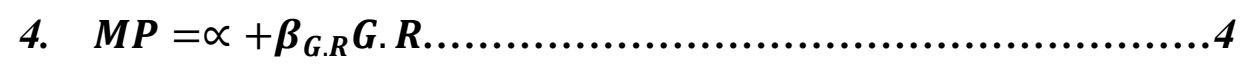

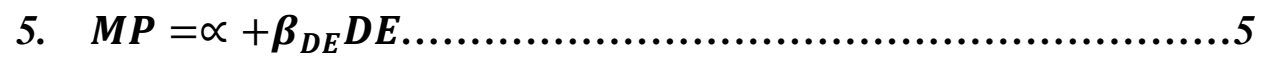

Where

BV=Book Value per Share (BV), calculated by BV= Net Assets/ Total outstanding shares

$B R V=$ Breakup Value of Shares

EPS $=$ Earnings per Share (EPS), is calculated by EPS $=$ Net Earnings $/$ Number of Outstanding Shares

$\mathbf{G R}=$ Gearing Ratio,is calculated by GR= Borrowing (all long-term debts + normal overdraft) / Net Assets (or Shareholders' Funds)

$\mathrm{DE}=$ Dividend to equity Ratio

4. Results and Discussion 
Table1. Simple Regression Results

\begin{tabular}{|r|r|r|r|r|}
\hline \multicolumn{7}{|c|}{ Model Summary } \\
\hline Model & \multicolumn{1}{|c|}{ R } & \multicolumn{1}{|c|}{ R Square } & $\begin{array}{c}\text { Adjusted R } \\
\text { Square }\end{array}$ & $\begin{array}{c}\text { Std. Error of } \\
\text { the Estimate }\end{array}$ \\
\hline 1 & $.478^{\mathrm{a}}$ & 0.229 & 0.224 & 26.49714 \\
\hline 2 & $.587^{\mathrm{a}}$ & 0.344 & 0.34 & 24.42881 \\
\hline 3 & $.332^{\mathrm{a}}$ & 0.11 & 0.105 & 28.45839 \\
\hline 4 & $.082^{\mathrm{a}}$ & 0.007 & 0 & 30.07098 \\
\hline 5 & $.287^{\mathrm{a}}$ & 0.083 & 0.077 & 28.89903 \\
\hline
\end{tabular}

\begin{tabular}{|c|c|c|c|c|c|}
\hline \multicolumn{6}{|c|}{ Coefficients } \\
\hline \multirow[t]{2}{*}{ Model } & \multicolumn{2}{|c|}{$\begin{array}{l}\text { Un-standadized } \\
\text { Coefficients }\end{array}$} & \multirow{2}{*}{$\begin{array}{l}\text { standadized } \\
\text { Coefficients } \\
\text { Beta }\end{array}$} & \multirow[t]{2}{*}{$\mathbf{T}$} & \multirow[t]{2}{*}{ Sig. } \\
\hline & B & std.Error & & & \\
\hline \multirow{2}{*}{$\begin{array}{l}1 \text { Constant } \\
\text { Book Value }\end{array}$} & 15.573 & 2.796 & & 5.569 & 0 \\
\hline & 0.195 & 0.029 & 0.478 & 6.759 & 0 \\
\hline \multirow{2}{*}{$\begin{array}{l}2 \text { Constant } \\
\text { Break Value }\end{array}$} & 18.395 & 2.222 & & 1.278 & 0.3 \\
\hline & 0.422 & 0.047 & 0.587 & 0.996 & 0.23 \\
\hline \multirow{2}{*}{$\begin{array}{l}3 \text { Constant } \\
\text { EPS }\end{array}$} & 27.808 & 2.279 & & 12.204 & 0 \\
\hline & 1.325 & 0.303 & 0.332 & 4.371 & 0 \\
\hline \multirow{2}{*}{$\begin{array}{l}4 \text { Constant } \\
\text { GR }\end{array}$} & 27.857 & 2.408 & & 11.57 & 0 \\
\hline & 0.009 & 0.009 & 0.082 & 1.02 & 0.309 \\
\hline \multirow{2}{*}{$\begin{array}{l}5 \text { Constant } \\
\text { DE }\end{array}$} & 24.298 & 2.506 & & 9.695 & 0 \\
\hline & 1.338 & 0.359 & 3.724 & 0.724 & 0.16 \\
\hline
\end{tabular}

\begin{tabular}{|l|r|r|r|l|l|}
\hline \multicolumn{7}{|c|}{ ANOVA } \\
\hline Model & $\begin{array}{l}\text { Sum of } \\
\text { Squares }\end{array}$ & \multicolumn{1}{|l|}{ Df } & $\begin{array}{l}\text { Mean } \\
\text { Square }\end{array}$ & F & Sig. \\
\hline 1 Regression & 32074.14 & 1 & 32074.15 & 45.683 & 0 \\
\hline Residual & 108123.131 & 154 & 702.098 & & \\
\hline Total & 140197.271 & 155 & & & \\
\hline 3 Regression & 15475.77 & 1 & 15475.77 & 19.109 & $.000 \mathrm{a}$ \\
\hline Residual & 124721.5 & 154 & 809.88 & & \\
\hline Total & 140197.271 & 155 & & & \\
\hline
\end{tabular}

The above posed tables describe the linear regression results of the suggested models. ANOVA table indicating that model 1 and model 3 are overall significant at alpha $1 \% 5 \%$ and $10 \%$. Model summary disseminates the information of adjusted r-squares of model. This summary shows that model 1 adjusted r-square is 22.2 percent while for the model 3 , 


\section{Macrothink}

is $10.5 \%$. We discuss only the significant model and excluded all the insignificant models.

Coefficient table displays that book value have significant positive influence on the market prices of the cement industry of Pakistan. Model 3 that states that earning per share is contributing positively in the market price, the coefficient of earning per share in coefficient table gave us the expected relationship, that earning per share is positively contributing in the market prices that is consistent with the prior studies as (Seetharaman\& Rudolph, 2010).

After checking the significance of the individual variable we test the influence of all significant variables together with the help of linear regression analysis. From the above results we conclude that book values and earnings per share are only two variables that influence market price significantly, so in the coming results we checked their impact together.

We develop following model

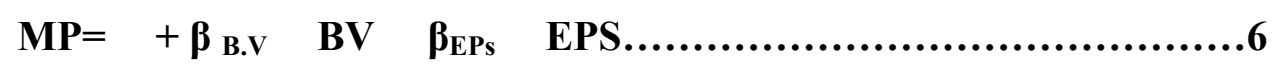

Where

MP $=$ Market Price

$\mathrm{BV}=$ Book Value

EPS $=$ Earnings per share

Table 2. Regression analysis reveals following results

\begin{tabular}{|l|l|l|l|l|}
\hline Model & R & R Square & Adjusted R square & Std.Error \\
\hline & $.650 \mathrm{a}$ & 0.422 & 0.415 & 23.01061 \\
\hline
\end{tabular}

\begin{tabular}{|l|l|l|l|l|l|}
\hline Model & $\begin{array}{l}\text { Sum of } \\
\text { Squares }\end{array}$ & Df & Mean Square & F & Sig. \\
\hline Regression & 59185.6 & 2 & 29592.8 & 55.889 & $.000 \mathrm{a}$ \\
\hline Residual & 81011.67 & 153 & 529.488 & & \\
\hline Total & 140197.3 & 155 & & & \\
\hline
\end{tabular}

\begin{tabular}{|l|l|l|l|l|l|}
\hline \multicolumn{7}{|c|}{ Coefficients } \\
\hline Model & \multicolumn{2}{|l|}{$\begin{array}{l}\text { Un-standadized } \\
\text { Coefficients }\end{array}$} & $\begin{array}{l}\text { standadized } \\
\text { Coefficients }\end{array}$ & T & Sig. \\
\hline & B & std.Error & Beta & & \\
\hline (Constant) & 13.096 & 2.453 & & 5.339 & 0 \\
\hline book Value & 0.232 & 0.026 & 0.571 & 9.086 & 0 \\
\hline Earnings per share & 1.792 & 0.25 & 0.449 & 7.156 & 0 \\
\hline
\end{tabular}


The summary of the model represents that overall model is healthy with the adjusted r-square 0.41 percent. Overall model is significant at even at $1 \%$. Model represent that there is a significant relationship between market value and accounting numbers of firms evident with $(0.233,0.000)$ which is consistent with the same line as (Willett \&Peare, 2000) and Graham and King (2000). Meanwhile earning per share could be used to predict the market price explained by $(1.792,0.000)$ in the coefficient table.

\section{Conclusion}

This study is an effort to investigate the relationship between the market value and accounting numbers of cement firms. Investors always try to predict the market prices to maximize their returns. Many researchers, practitioner and investors have tried to predict the market prices with different methods and variables. But even though extensive body of literature in this issue is available, but still unsolved issue and requires more research.

That's why we try to contribute in this issue in Pakistani case. Firstly we suggested five variables that could be helpful in predicting the market prices. At the first stage three of them found insignificant and we excluded that variables.

In the final stage, we found that accounting numbers have positive influence on the market prices that has been argued many researchers in the existing literature. We also find this relationship in Pakistani market. Secondly we conclude that earning per share is statistically has significant influence on the market prices. These both variables are highly influence on market prices in the Pakistan scenario.

Also this study has some limitations. Firstly this study scope is limited to the Pakistani stock market and could not be generalized. Second issue is this due to certain reasons this study only discusses the cement industry of the Pakistan, although it is rich industry we could not say these things for other sectors with surety. This study could be helpful for investor for predicting the prices and researches to extend this idea to the rest of sectors of the economy.

\section{References}

Ball, R., \& Brown, P. (1968). An Empirical Evaluation of Accounting Income and Numbers. Journal of Accounting Research, Autumn, 159-177. http://dx.doi.org/10.2307/2490232

Ball, R., Kothari, S. P., \& Watts, R. L. (1993).Economic determinants of the relation between earnings changes and stock returns. Accounting Review, 622-638.

Bartholdy, J., Peare, P., \& Willett, R. J. (2000). A theoretical and empirical analysis of the relationship between market and book values.

Clout, V. J. (2007). Investigating the Relationship between Market Values and Accounting Numbers for 30 Selected Australian Listed Companies (Doctoral dissertation, School of Accountancy, Faculty of Business, Queensland University of Technology).

Lamont, O. (1992). Earnings and expected returns. Journal of Finance, 5, 1563-1587. 


\section{Macrothink}

Asian Journal of Finance \& Accounting ISSN 1946-052X 2015, Vol. 7, No. 1

Omura, T. (2005). The relationship between market value and book value for five selected Japanese firms.

Petkova.R.,\& Zhang. L. (2005). Is value riskier than growth? Journal of Financial Economics 78(1), 187-202. http://dx.doi.org/10.1016/j.jfineco.2004.12.001

Previts, G. J., Bricker, R. J., Robinson, T. R., \& Young, S. J. (1994). A content analysis of sell-side financial analyst company reports. Accounting Horizons, 8, 55-55.

Raj, H., \& Ramesh, P. R. (1992). Price/book value ratios and equity returns on the Tokyo stock exchange: Empirical evidence of an Anomalous Regularities. The Financial Review, 27(4).

Suwardi, E. (2004). Exploring the relationship between market values and accounting numbers of firms listed in an emerging market (Doctoral dissertation, Queensland University of Technology).

Vafeas, N., Trigeorgis., L., and Georgiou., X. (1998). The Usefulness of Earnings in Explaining Stock Returns in an Emerging Market: The Case of Cyprus. European Accounting Review, 7(1), 105-126. http://dx.doi.org/10.1080/096381898336600

Zulkifli, M., \& Kadri, M. H. (2008). Relationship between market value and book value of Malaysian firms under pre and post FRS. http://dx.doi.org/10.2139/ssrn.1440771 